ORIGINAL ARTICLE, MEDICINE

\title{
Vitamin K2 Improves Anxiety and Depression but not Cognition in Rats with Metabolic Syndrome: a Role of Blood Glucose?
}

\author{
Silvia M. Gancheva, Maria D.Zhelyazkova-Savova \\ Department of Preclinical and Clinical Pharmacology, Medical University of Varna, Varna, Bulgaria
}

\section{Correspondence:}

Silvia M. Gancheva, Department of Preclinical and Clinical Pharmacology, Medical University of Varna, 55 Marin Drinov St., 9002 Varna, Bulgaria

E-mail: silvi_gancheva@abv.bg Tel: +359887497689

Received: 11 Nov 2015

Accepted: 05 July 2016

Published Online: 05 Oct 2016

Published: 23 Dec 2016

Key words: vitamin K2, metabolic syndrome, anxiety, depression, correlation with blood glucose

Citation: Gancheva SM, Zhelyazkova-Savova MD. Vitamin K2 improves anxiety and depression but not cognition in rats with metabolic syndrome: a role of blood glucose?

Folia Medica 2016;58(4):264-272 doi: 10.1515/folmed-2016-0032
Background: The metabolic syndrome is a socially important disorder of energy utilization and storage, recognized as a factor predisposing to the development of depression, anxiety and cognitive impairment in humans.

Aim: In the present study we examined the effects of vitamin K2 on the behavior of rats with metabolic syndrome and looked for relationships with the effects on blood sugar.

Materials and methods: Male Wistar rats were divided in four groups: a control group on a regular rat chow, a metabolic syndrome (MS) group fed a highfat high-fructose diet, a control group treated with vitamin K2 and a MS group treated with vitamin K2. Vitamin K2 was given by gavage. At the end of the study (after 10 weeks) behavioral tests were performed and fasting blood glucose was measured. Anxiety was determined using the social interaction test and depression was assessed by the Porsolt test. Memory effects were estimated by the object recognition test. Correlations between fasting blood glucose and behavioral performance were analyzed.

Results: The rats from the MS group had elevated blood glucose. They had anxiety, depression and memory deficit. Vitamin K2 normalized blood glucose, reduced anxiety and depression, but did not improve memory. Time of social interaction (inverse index of anxiety) and memory recognition were negatively correlated with blood glucose in the untreated rats but the immobility time (measure of depression) was not. When vitamin K2-treated rats were added, the correlation of blood glucose with the time of social interaction was kept, but the one with the recognition memory was lost. It might be that the anxiolytic effect of vitamin $\mathrm{K} 2$ in this setting is at least partly due to its effects on blood glucose, while the antidepressant effect is glucose-independent.

Conclusion: The present study demonstrated that vitamin $\mathrm{K} 2$ prevented the development of anxiety and depression, but did not improve the memory deficit caused by the dietary manipulation in an experimental model of metabolic syndrome. It might be that the anxiolytic effect of vitamin K2 is at least partly due to its effects on blood glucose, while the antidepressant effect is glucoseindependent.

\section{BACKGROUND}

The metabolic syndrome is a socially important disorder of energy utilization and storage, comprising central obesity, hypertriglyceridemia, reduced HDL-cholesterol and raised fasting plasma glucose. It has been estimated that about 20-25 percent of the adult population of the world are affected by this condition. It is a widely known risk factor for the development of cardiovascular diseases and type 2 diabetes. However, it has also been recognized as a factor predisposing to the development of neuropsychiatric disorders, such as depression ${ }^{1}$ and anxiety ${ }^{2}$. Obesity is also known to be associated with cognitive impairment in humans. ${ }^{3}$ The epidemiological observations have triggered experimental research aiming at proving and elucidating these relationships.

Vitamin $\mathrm{K}$ is the family name of structurally related fat-soluble vitamins. Vitamin K1 (phylloquinone) performs the classic functions of vitamin $\mathrm{K}$ - it activates vitamin $\mathrm{K}$-dependent clotting factors and anticoagulant proteins. Vitamin K2 is a family 
of homologues known as menaquinones. It appears that they are mainly acting outside the liver. ${ }^{4}$ Extrahepatic actions of menaquinones require higher dietary intake of vitamin $\mathrm{K}$ than needed to maintain physiological coagulation status. ${ }^{5}$ According to Professor Bruce Ames' "triage theory", the subclinical vitamin $\mathrm{K}$ deficit, without affecting the coagulation status, is widespread and is probably connected to the pathogenesis of diseases associated with aging. ${ }^{6}$

Metabolic disorders belong to this type of aging diseases and large epidemiological studies have confirmed that high dietary vitamin $\mathrm{K}$ intake is associated with reduced risk of metabolic syndrome ${ }^{7}$ and diabetes type $2^{8,9}$. The metabolic effects of vitamin $\mathrm{K}$ have been studied in intact rats ${ }^{10}$ and in rats with streptozotocin-induced diabetes ${ }^{11}$ but not in rats subjected to experimental models of metabolic syndrome.

The effects of vitamin $\mathrm{K}$ on the central nervous system have been studied mainly in in vitro conditions. They have shown that vitamin K, based on its antioxidant actions ${ }^{12,13}$, protects neurons and oligodendrocytes from oxidative damage ${ }^{14}$ and have proved that the naphthoquinone ring is responsible for the neuroprotective action ${ }^{15}$. A possible role of vitamin $\mathrm{K}$ deficiency in pathogenesis of neurodegenerative diseases has been suggested. ${ }^{16}$ Behavioral effects of vitamin $\mathrm{K}$ on rats, either intact or with metabolic syndrome, have not been studied.

In the present study we examined the behavioral effects of vitamin $\mathrm{K} 2$ in intact rats and in rats with metabolic syndrome and looked for relationships between these effects and changes in the fasting blood glucose levels caused by the vitamin K2 treatment.

\section{MATERIALS AND METHODS}

\section{EXPERIMENTAL ANIMALS}

The study included 40 male Wistar rats. The animals were kept at an ambient temperature of $20-25^{\circ} \mathrm{C}$, 12-hour light-dark cycle and free access to food and water. The study was approved by the Foods Safety Commission in the Ministry of Agriculture and Foods.

The experimental animals were allocated in 4 groups of 10 rats each, with initial body weight ranging between 220 and $296 \mathrm{~g}$ (on the average, $262 \mathrm{~g}$ in each group). The duration of the study was 10 weeks. The groups were as follows: group $\mathrm{C}$ (control), group K2 (control rats treated with vitamin K2), group MS (rats with metabolic syndrome) and group $\mathrm{K} 2+\mathrm{MS}$ (rats with metabolic syndrome treated with vitamin $\mathrm{K} 2$ ).

\section{DiETS AND TREATMENT}

The rats from groups $\mathrm{C}$ and $\mathrm{K} 2$ were fed a standard rat chow and were given plain water to drink. With each $100 \mathrm{~g}$ food consumed, the animals from these groups had a caloric intake of $279 \mathrm{kcal}$. The rats from groups MS and $\mathrm{K} 2+\mathrm{MS}$ were subjected to a diet-induced metabolic syndrome. ${ }^{17}$ They were given a high fat high fructose (HFHF) diet with lard (17\%) and fructose $(17 \%)$ added to the standard rat chow and a $10 \%$ fructose solution instead of drinking water. The caloric intake was $405 \mathrm{kcal}$ per $100 \mathrm{~g}$ food and $40 \mathrm{kcal}$ per $100 \mathrm{ml}$ water.

Groups K2 and K2+MS were treated with vitamin K2 purchased from Seebio Biotech, Inc., in the form of $1.3 \%$ oily solution of menaquinone- 7 in sunflower oil. Vitamin K2 was administered orally in a dose of $35 \mathrm{mg} / \mathrm{kg}(0.2 \mathrm{ml}$ oily solution per $100 \mathrm{~g}$ body weight) through an intragastral gavage 5 days in a week, from Monday to Friday, for 10 weeks. Since vitamin K2 was dissolved in sunflower oil, the rats from $\mathrm{C}$ and MS groups received the vehicle, sunflower oil, at the same amount and manner.

\section{FASTING BLOOD GLUCOSE DETERMINATION}

At the end of the study rats were fasted for 4 hours and blood glucose was measured. Blood samples were taken by incision of the distal part of the tail. ${ }^{18}$ Blood glucose levels were measured by a glucometer (ACCU-CHEK Performa).

\section{BEHAVIORAL TESTS}

The behavioural test were performed after 10 weeks of diet loading and vitamin $\mathrm{K} 2$ treatment.

\section{Social interaction test}

Social interaction test is often used to measure the level of anxiety. ${ }^{19}$ It was performed in uniformly lighted square field $(100 \times 100 \mathrm{~cm})$ with surrounding walls $40 \mathrm{~cm}$ high to prevent escape. The field was painted white except for $6 \mathrm{~mm}$ blue lines that divided the floor into 25 equal size squares $(20 \times 20$ $\mathrm{cm})$. Each rat was tested with an unknown partner with similar weight. Both members of a pair were fed or treated in the same way. The rats were placed simultaneously in the opposite corners of the area. Their behavior was observed in silence for 5 minutes and the time of social interaction was recorded for each rat. The active interactions such as sniffing, grooming, following, crawling under or over the partner were scored. The passive contact (sitting or lying with bodies in contact) was not considered as a social interaction time. 


\section{Forced swim test}

The forced swim test, designed by Porsolt ${ }^{20}$, is a routinely used test to determine the depression-like state of rodents. Each rat was put in a glass cylinder (17 cm diameter and $60 \mathrm{~cm}$ height) full with water $\left(25^{\circ} \mathrm{C}\right)$ and its behavior was observed for 5 minutes. The water was $30 \mathrm{~cm}$ deep so the animals could not touch the bottom with their tails or feet. The immobility time was recorded as a measure of depressive behavior.

\section{Object recognition test}

Object recognition test is used as a screening test for working memory. ${ }^{21}$ It was performed in a uniformly lighted rectangular area $(60 \times 60 \mathrm{~cm})$ surrounded by $40 \mathrm{~cm}$ walls. The training session was performed with two identical objects - cubes made of gypsum that were sufficiently heavy to prevent their moving by the rats. Objects were placed symmetrically. Exploration, defined as orienting toward the object from a distance of $1 \mathrm{~cm}$ or less, actively sniffing or climbing on the object, was measured for 3 minutes. The session with a novel object was performed 5 hours later. Each animal was placed in the area with one of the cubes and the novel object (a gypsum-made pyramid) and was allowed to explore the objects for 3 minutes. The time spent in exploration of the novel object (B) and the old object $(\mathrm{A})$ was recorded. The discrimination ratio $\mathrm{B} /$ $(\mathrm{A}+\mathrm{B})$ was calculated. It is the time that a rat spent exploring the novel object relative to the total time of exploration of both objects. The discrimination ratio was used as a measure of recognition memory.

Fasting blood glucose

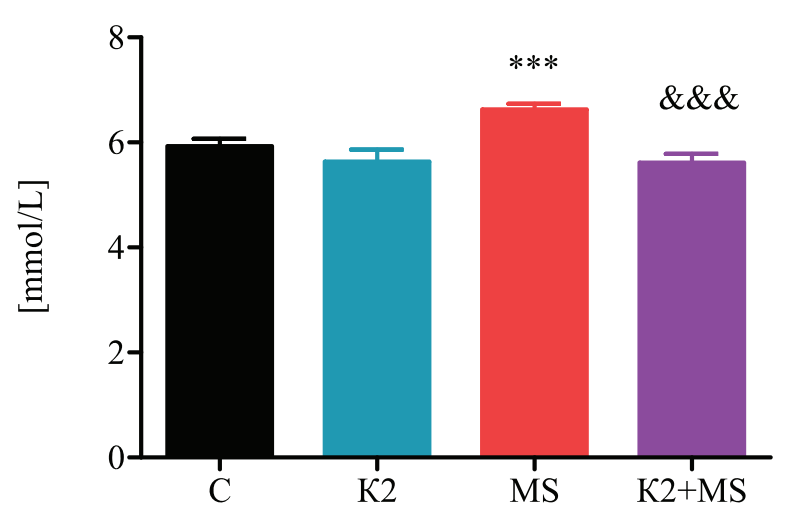

Figure 1. Fasting blood glucose levels; $\mathrm{C}$ - control rats, $\mathrm{K} 2$ - control rats treated with vitamin $\mathrm{K} 2$, MS - rats with metabolic syndrome, $\mathrm{K} 2+\mathrm{MS}$ - rats with metabolic syndrome treated with vitamin $\mathrm{K} 2$; *** $\mathrm{p}<0.001$ vs $\mathrm{C}$; $\& \& \& \mathrm{p}<0.001$ vs MS.

\section{Statistical ANALYSIS}

Results are presented as a mean \pm SEM. The results from two groups ( $\mathrm{C}$ and $\mathrm{MS}$; MS and $\mathrm{K} 2+\mathrm{MS}$ ) were Social interaction test

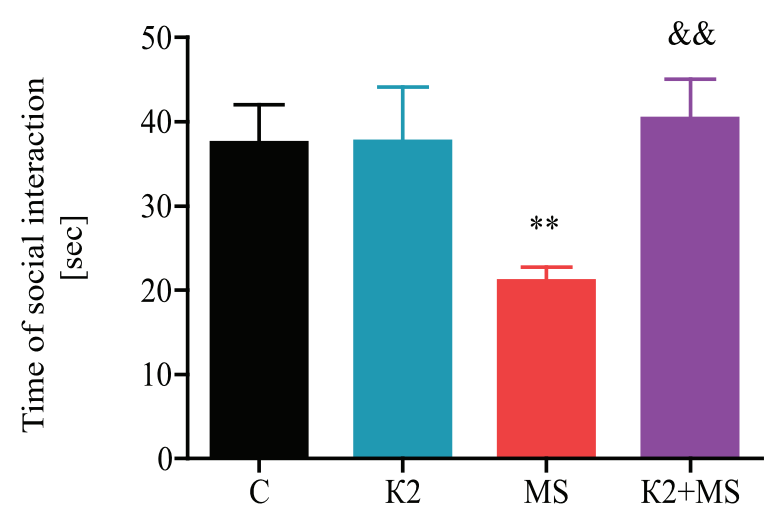

B

Forced swim test

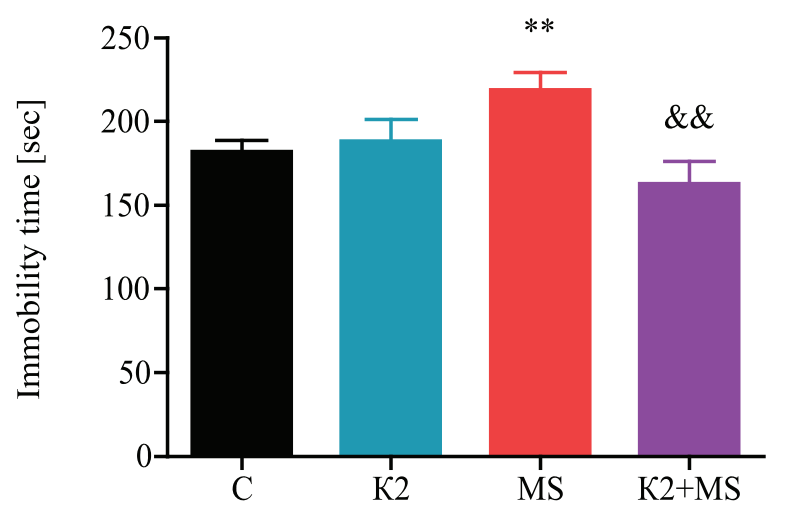

C

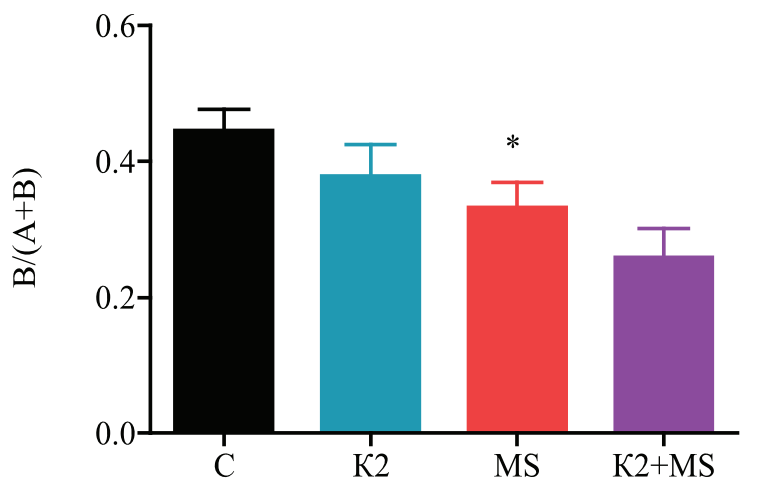

Figure 2. Behavioral tests: social interaction test (A), forced swim test (B) and object recognition test (C); $\mathrm{C}$ - control rats, $\mathrm{K} 2$ - control rats treated with vitamin $\mathrm{K} 2$, MS - rats with metabolic syndrome, $\mathrm{K} 2+\mathrm{MS}$ - rats with metabolic syndrome treated with vitamin $\mathrm{K} 2$; $* p<0.05, * * p<0.01$ vs $C ; \& \& p<0.01$ vs MS. 
analyzed with unpaired $t$ test. Association between behavioral results and fasting blood glucose were analyzed by correlation analysis and linear regression. A level of $p<0.05$ was considered significant. Analyses were performed using GraphPad Prism statistical software.

\section{RESULTS}

Fasting blood glucose levels are presented in Fig. 1. There was no difference between group $\mathrm{C}$ and group K2. Dietary manipulated rats (MS group) had a higher blood glucose level: $6.633 \pm 0.1054$ $\mathrm{mmol} / \mathrm{L}$ compared to $5.930 \pm 0.1375 \mathrm{mmol} / \mathrm{L}$ in group $\mathrm{C}(\mathrm{t}=3.991, \mathrm{p}=0.0009)$. In group $\mathrm{K} 2+\mathrm{MS}$ the fasting plasma glucose was $5.617 \pm 0.1662 \mathrm{mmol} / \mathrm{L}$ $(\mathrm{t}=5.450, \mathrm{p}=0.0001 \mathrm{vs} \mathrm{MS})$.

Results from the behavioral tests are presented in Fig. 2. In all the tests vitamin $\mathrm{K} 2$ caused no changes in the behavior of the rats compared to the control group. Rats from the MS group demonstrated decreased time of social interaction $(21.13 \pm 1.663 \mathrm{sec}$ vs $37.56 \pm 4.482 \mathrm{sec}$ in group $\mathrm{C}, \mathrm{t}=3.273, \mathrm{p}=0.0051$ ) - a sign of anxiety-like behavior (Fig. 2A). They had also increased immobility time in the forced swim test $(219.0 \pm 10.20 \mathrm{sec}$ vs $181.9 \pm 6.730 \mathrm{sec}$ in group $\mathrm{C}, \mathrm{t}=2.981, \mathrm{p}=0.0067)$, revealing depressionlike behavior (Fig. 2B). In the object recognition test the discrimination ratio was decreased in the MS group $(0.3327 \pm 0.03588$ vs $0.4455 \pm 0.03099$ in the $\mathrm{C}$ group, $\mathrm{t}=2.378, \mathrm{p}=0.0275)$, implying memory impairment (Fig. 2C). Treatment with vitamin K2 counteracted anxiety (social interaction time in the K2+MS group was $40.40 \pm 4.700 \mathrm{sec}, \mathrm{t}=3.511$, $\mathrm{p}=0.0029$ vs MS) and depression (immobility time in the K2+MS group was $162.9 \pm 13.42 \mathrm{sec}, \mathrm{t}=3.294$, $\mathrm{p}=0.0040$ vs MS) but did not improve memory function of rats subjected to diet manipulation.

The results from the correlation analyses are shown in Fig. 3. The effect of vitamin K2 was differentially correlated with blood sugar in the 3 behavioral tests. In the social interaction test (Fig. 3A), there was an inverse correlation between the fasting blood glucose and the time of social interaction when only rats from the $\mathrm{C}$ and the MS groups were analyzed (Pearson $\mathrm{r}=-0.6306, \mathrm{p}=0.0088$ ). The inverse correlation was preserved when rats from the $\mathrm{K} 2$ and the $\mathrm{K} 2+\mathrm{MS}$ groups were added (Pearson $\mathrm{r}=-0.4417, \mathrm{p}=0.0129)$. In the forced swim test (Fig. 3B), no correlation was found between the blood glucose and the immobility time, neither when only vitamin $\mathrm{K} 2$ untreated animals were analyzed, nor when all animals were included in analysis. In the object recognition test (Fig. 3C), an inverse correlation between the fasting blood glucose and the discrimination ratio was found among vitamin K2 untreated rats (C and MS groups - Pearson $\mathrm{r}=-0.5944, \mathrm{p}=0.0152)$. When vitamin $\mathrm{K} 2$-treated rats were added to the analysis ( $\mathrm{K} 2$ and $\mathrm{K} 2+\mathrm{MS}$ groups), the correlation was lost.

\section{DISCUSSION}

The results from the present study suggest that rats with diet-induced metabolic syndrome developed increased anxiety, depression-like behavior and memory impairment. In our previous ${ }^{17}$ and present experiments the metabolic syndrome was verified by visceral obesity and biochemical parameters, which also included elevated fasting blood glucose. Vitamin K2 treatment prevented the elevation of fasting blood glucose - a result consistent with findings reported in the literature for humans $\mathrm{s}^{22}$ and diabetic rats ${ }^{10,11}$. Indeed, our study is the first to show an anti-hyperglycemic effect of vitamin $\mathrm{K} 2$ in rats subjected to HFHF diet-induced metabolic syndrome. We also have demonstrated for the first time that vitamin $\mathrm{K} 2$ is capable of exerting antianxiety and antidepressant effects.

\section{EFFECTS ON ANXIETY}

There is limited evidence of the coexistence of anxiety in metabolic syndrome patients - it seems to be a byproduct of anxiety-depression comorbidity, stress and negative health behaviors. ${ }^{23}$ Although moderate level of evidence exists for a positive association between obesity and anxiety disorders, the exact association between these two conditions is not yet clear. ${ }^{24}$

The results from experimental studies are quite inconsistent. Both reduced and increased anxiety measures have been found in rodents fed high-caloric diets containing fat, sugars or both. ${ }^{25}$ Some of the studies have observed gender-dependent changes in anxiety ${ }^{26,27}$ implying that female rats may react by reduced anxiety to diet-induced metabolic changes. Increased anxiety has been found in streptozotocininduced diabetes in mice. ${ }^{28}$

Similarly to Buchenauer ${ }^{29}$ and Sousa ${ }^{30}$, we found that feeding rats with diet rich in lard and fructose increased their level of anxiety. Our results further show that anxiety correlated with the fasting blood glucose, implying that metabolic changes might be, at least in part, responsible for the dietary anxiogenic effect. The association between anxiety and blood glucose imbalances is not widely addressed 
A

Blood glucose vs time of social interaction in vitamin $\mathrm{K} 2$ untreated rats

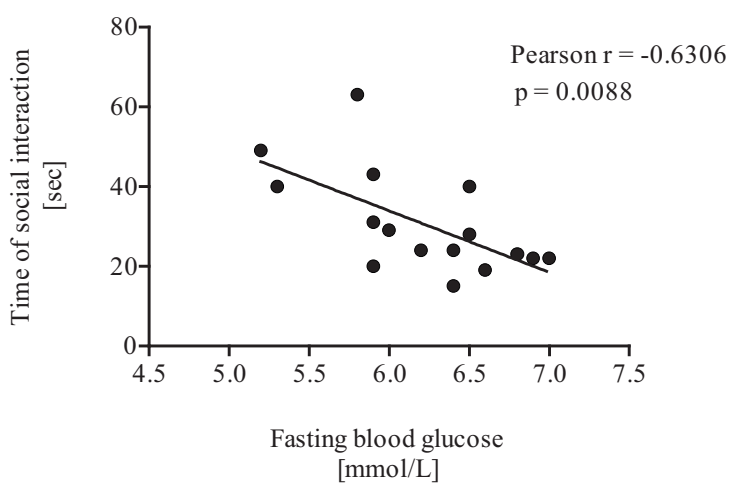

B

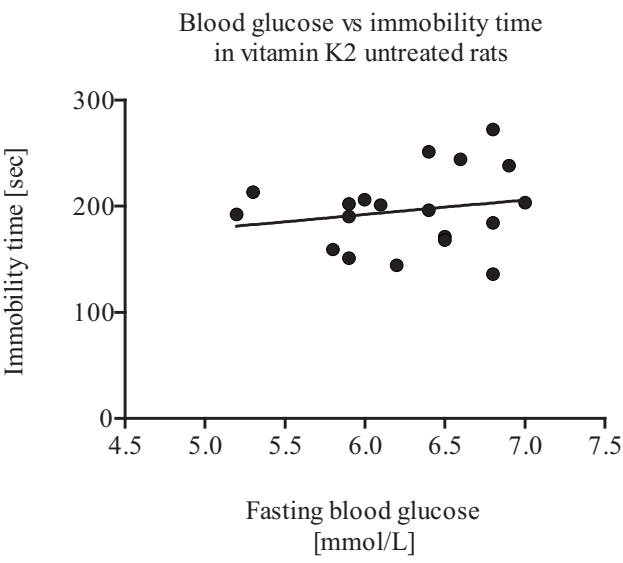

C

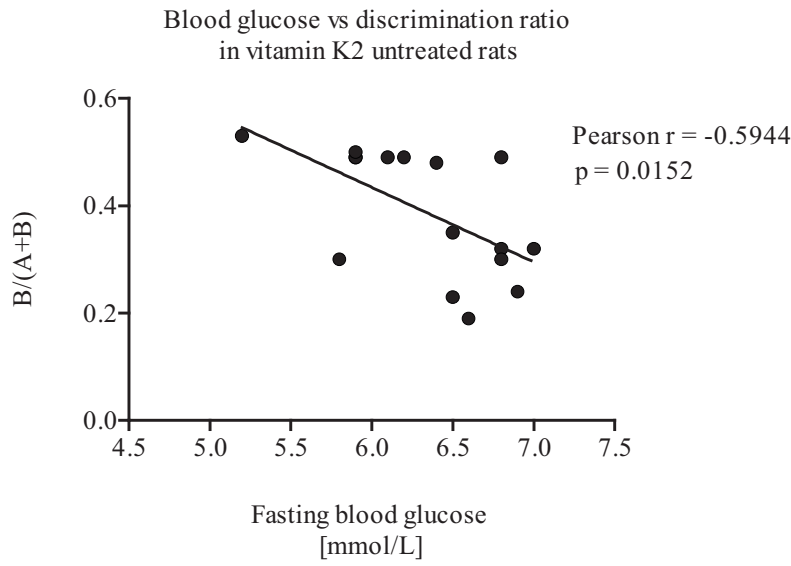

Blood glucose vs time of social interaction in vitamin $\mathrm{K} 2$ untreated and treated rats
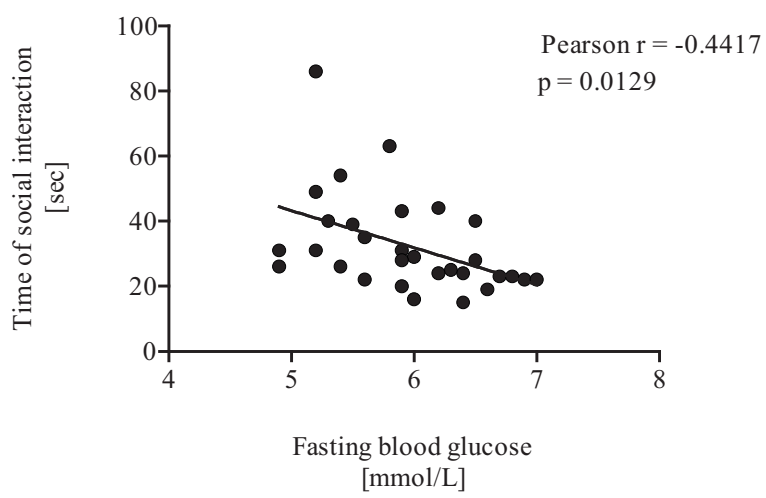

Blood glucose vs immobility time in vitamin K2 untreated and treated rats
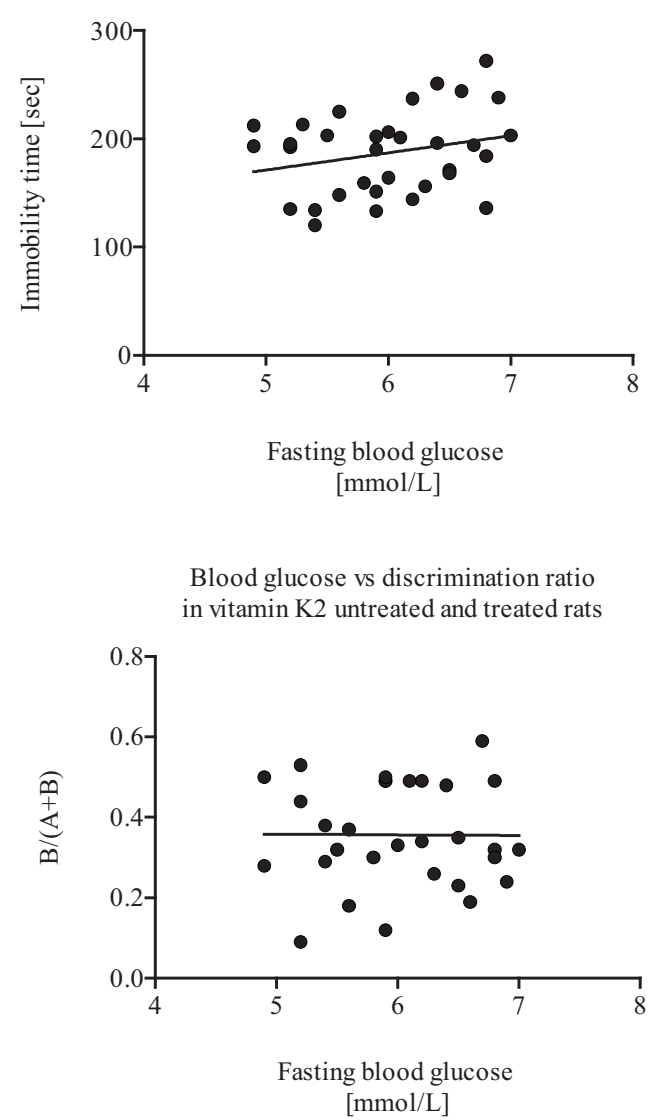

Figure 3. Comparison between the correlations of fasting blood glucose vs the results from the social interaction test (A), forced swim test (B) and object recognition test $(\mathrm{C})$ in vitamin $\mathrm{K} 2$ untreated and in all rats (vitamin $\mathrm{K} 2$ untreated and treated rats).

in the literature. Nevertheless, according to a metaanalysis, anxiety determined by diagnostic interviews is highly associated with hyperglycemia in patients with type 1 and type 2 diabetes. ${ }^{31}$

An interesting finding in our study was that vitamin $\mathrm{K} 2$ treatment prevented not only the increase of plasma glucose, but it also antagonized the HFHF diet-induced anxiety. In addition, vitamin
K2 treatment preserved the association between hyperglycemia and anxiety. The effect of vitamin $\mathrm{K} 2$ on rat anxiety thus seems to be linked with the effect on blood glucose. Moreover, this is the first study to demonstrate an anxiolytic effect of MK-7 in rats with MS, while exerting no effect in intact animals. The two effects observed appear to be at least connected with each other, if not inter-related. 


\section{EFFECTS ON DEPRESSION}

Association between metabolic and depressive disorders has been reported in a number of clinical settings and modelled in experimental studies. Mood disorders and metabolic syndrome have been shown to present overlapping pathophysiology where multiple factors such as insulin and leptin resistance, pro-inflammatory cytokines, reactive oxygen species, glucocorticoids are involved in a complex interplay in the brain. 32,33

The results from our study showed that rats subjected to the dietary model of metabolic syndrome displayed increased immobility time in the forced swim test consistent with depression-like behavior. This behavior was antagonized by the treatment with vitamin K2. The score of depression, however, unlike the score of anxiety, did not correlate with blood glucose levels both in untreated rats and in those treated with vitamin $\mathrm{K} 2$. We can speculate therefore that the antidepressant effect of vitamin $\mathrm{K} 2$ is not directly related to its effects on blood sugar. Rather, it could potentially be due to its antioxidant and anti-inflammatory actions. Vitamin K1 and K2 have been shown to prevent oxidative injury to developing oligodendrocytes and neurons ${ }^{14}$ and vitamin $\mathrm{K} 2$ has been found to be the more potent neuroprotective agent in vitro ${ }^{15}$. A recent epidemiological study on the dietary intake of phylloquinone has found a longitudinal reduction effect on pro-inflammatory markers, related to insulin resistance and diabetes. ${ }^{34}$ Thus, it is feasible to relate the observed effect of vitamin $\mathrm{K} 2$ on depression in rats with diet-induced metabolic syndrome to its ability to prevent or reduce the impact of inflammation and oxidative stress on this behavior.

\section{EFFECTS ON MEMORY}

Metabolic syndrome and obesity are known to affect cognition and raise the risk of dementia. ${ }^{35}$ In our study we observed a lower discrimination ratio in the animals fed HFHF diet compared to control rats, consistent with other experimental works on cognitive functions. Most authors report on impairments in the spatial memory ${ }^{36}$, which appears to be more sensitive to dietary intervention compared to recognition and other types of non-spatial working memory ${ }^{37,38}$. In the current study we demonstrated that in rats subjected to HFHF diet for a long enough period of time the recognition memory impairment was correlated with fasting glucose levels, similarly to the findings of Jurdak and Kanarek. ${ }^{39}$ The treatment with vitamin $\mathrm{K} 2$, however, did not counteract the memory deficit irrespective of its effect on the fasting blood glucose.

The brain structure mostly involved in memory formation is the hippocampus, and it is mainly responsible for spatial memory. ${ }^{40}$ As for the recognition memory, it is the perirhinal cortex that is thought to be involved in object recognition after short retention intervals, while the hippocampus is responsible for the long-term object recognition. ${ }^{41}$ Cognitive impairment in diet-induced metabolic disorders has been associated with hippocampal damage, including inflammation and oxidative stress ${ }^{36}$; less is known about the postulated biological mechanisms of non-spatial memory deficits.

The finding of inefficacy of vitamin K2 to prevent the cognitive impairment in our study was somewhat unexpected, given the antioxidant ${ }^{14}$, neuroprotective ${ }^{15}$, and anti-inflammatory ${ }^{34}$ properties described in the literature. Due to its regulation of sulfotransferase activity and the activity of a growth factor/tyrosine kinase receptor (Gas 6/Axl) in the brain a hypothesis has been proposed that vitamin $\mathrm{K}$ deficiency contributes to the pathogenesis of Alzheimer's disease. ${ }^{16}$ Moreover, a recent study among geriatric patients revealed improved cognition associated with higher dietary intake of vitamin $\mathrm{K} .{ }^{42} \mathrm{~A}$ possible explanation of the negative results in our experiments would be that this particular test for measuring memory impairment in diet-induced metabolic syndrome is for some reason insensitive to vitamin K2. Alternatively, it might be that the brain structures involved in this type of memory are not particularly affected by oxidative stress and inflammation through the metabolic disturbances of the model used. ${ }^{43}$

\section{CONCLUSION}

The present study has demonstrated that the high-fat high-fructose diet-induced metabolic syndrome in rats is associated with development of behavioral disorders such as anxiety, depression and cognitive impairment. Vitamin K2 treatment prevented the elevation of fasting blood glucose level caused by the dietary manipulation and also the development of anxiety and depression. However, it did not improve the memory deficit. The effect of vitamin K2 was differentially correlated with blood sugar in the three behavioral tests hence we concluded that the anxiolytic effect of vitamin K2 is probably mediated, at least in part, by its action on blood sugar while the antidepressant effect of vitamin K2 is unrelated to its effect on blood glucose. 


\section{REFERENCES}

1. McElroy SL, Kotwal R, Malhotra S, et al. Are mood disorders and obesity related? A review for the mental health professional. J Clin Psychiatry 2004;65(5):634-51.

2. Gariepy G, Nitka D, Schmitz N. The association between obesity and anxiety disorders in the population: a systematic review and meta-analysis. Int J Obesity 2010;34:407-19.

3. Elias MF, Elias PK, Sullivan LM, et al. Obesity, diabetes and cognitive deficit: The Framingham heart study. Neurobiol Aging 2005;26(1):11-6.

4. Thijssen H, Drittij-Reijnders M. Vitamin K status in human tissues: tissue-specific accumulation of phylloquinone and menaquinone-4. Br J Nutr 1996;75:121-7.

5. Schurgers L, Spronk H, Soute B, et al. Regression of warfarin-induced medial elastocalcinosis by high intake of vitamin K in rats. Blood 2007;109:2823-31.

6. McCann J, Ames B. Vitamin K, an example of triage theory: is micronutrient inadequacy linked to diseases of aging? Am J Clin Nutr 2009;90(4):889-907.

7. Pan Y, Jackson R. Dietary phylloquinone intakes and metabolic syndrome in US young adults. J Am Coll Nutr. 2009;28(4):369-79.

8. Beulens J, van der A D, Grobbee D, et al. Dietary phylloquinone and menaquinones intakes and risk of type 2 diabetes. Diabetes Care 2010;33:1699-705.

9. Ibarrola-Jurado N, Salas-Salvado J, MartinezGonzalez M, et al. Dietary phylloquinone intake and risk of type 2 diabetes in elderly subjects at high risk of cardiovascular disease. Am J Clin Nutr 2012;96(5):1113-18.

10. Sogabe N, Maruyama R, Baba O, et al. Effects of long-term vitamin K1 (phylloquinone) or vitamin K2 (menaquinone-4) supplementation on body composition and serum parameters in rats. Bone 2011;48(5):1036-42.

11. Seyama Y, Kimoto S, Marukawa Y, et al. Comparative effects of vitamin K2 and estradiol on experimental arteriosclerosis with diabetes mellitus. Int J Vitam Nutr Res 2000;70(6):301-4.

12. Mukai K, Itoh S, Morimoto H. Stopped-flow kinetic study of vitamin E regeneration reaction with biological hydroquinones (reduced forms of ubiquinone, vitamin $\mathrm{K}$, and tocopherolquinone) in solution. $\mathrm{J}$ Biol Chem 1992;267:22277-81.

13. Westhofen P, Watzka M, Marinova M, et al. Human vitamin $\mathrm{K}$ 2,3-epoxide reductase complex subunit 1-like 1 (VKORC1L1) mediates vitamin K-dependent intracellular antioxidant function. J Biol Chem 2011;286(17):15085-94.

14. Li J, Lin J, Wang H, et al. Novel role of vitamin K in preventing oxidative injury to developing oligodendrocytes and neurons. J Neurosci 2003;23(13):5816-26.

15. Josey B, Inks E, Wen X, et al. Structure-activity relationship study of Vitamin $\mathrm{K}$ derivatives yields highly potent neuroprotective agents. J Med Chem 2013;56(3):1007-22.

16. Allison A. The possible role of vitamin K deficiency in the pathogenesis of Alzheimer's disease and in augmenting brain damage associated with cardiovascular disease. Med Hypotheses 2001;57(2):151-5.

17. Gancheva S, Zhelyazkova-Savova M, Galunska B, et al. Experimental models of metabolic syndrome in rats. Scr Sci Med 2015;47(2):23-30.

18. Fluttert M, Dalm S, Oitzl M. A refined method for sequential blood sampling by tail incision in rats. Laboratory Animals 2000;34:372-8.

19. File SE, Hyde JRG. Can social interaction be used to measure anxiety? Br J Pharmacol 1978;62:19-24.

20. Porsolt RD. Animal model of depression. Biomedicine 1979;30(3):139-40.

21. Ennaceur A. One-trial object recognition in rats and mice: methodological and theoretical issues. Behav Brain Res 2010;215:244-54.

22. Sakamoto N, Nishiike T, Iguchi H, et al. Possible effects of one week vitamin $\mathrm{K}$ (menaquinone-4) tablets intake on glucose tolerance in healthy young male volunteers with different descarboxy prothrombin levels. Clin Nutr 2000;19:259-63.

23. Sardinha A, Nardi AE. The role of anxiety in metabolic syndrome. Expert Rev Endocrinol Metab 2012; 7(1):63-71.

24. Lykouras L, Michopoulos J. Anxiety disorders and obesity. Psychiatriki 2011;22(4):307-13.

25. Murphy M, Mercer JG. Diet-regulated anxiety. Int J Endocrinol 2013;2013:701967.

26. Lalanza JF, Caimari A, del Bas JM, et al. Effects of a post-weaning cafeteria diet in young rats: metabolic syndrome, reduced activity and low anxiety-like behaviour. PLoS ONE 2014;9(1):e85049.

27. Warneke W, Klaus S, Fink H, et al. The impact of cafeteria diet feeding on physiology and anxietyrelated behaviour in male and female SpragueDawley rats of different ages. Pharmacol Biochem Behav 2014;116:45-54.

28. Gupta D, Radhakrishnan M, Kurhe Y. Insulin reverses anxiety-like behavior evoked by streptozotocin-induced diabetes in mice. Metabolic Brain Dis 2014;29(3):737-46.

29. Buchenauer T, Behrendt P, Bode FJ, et al. Dietinduced obesity alters behavior as well as serum levels of corticosterone in F344 rats. Physiol Behav 2009;98:563-9.

30. Souza CG, Moreira JD, Siqueira IR, et al. Highly palatable diet consumption increases protein oxidation in rat frontal cortex and anxiety-like behavior. Life Sci 2007;81:198-203.

31. Anderson RJ, Grigsby AB, Freedland KE, et al. Anxiety and poor glycemic control: a meta-analytic review of the literature. Int J Psychiatry Med 2002;32(3):235-47.

32. McIntyre RS, Soczynska JK, Konarski JZ, et al. 
Should depressive syndromes be reclassified as "metabolic syndrome type II"? Ann Clin Psychiatry 2007;19(4):257-64.

33. Berk M, Williams LJ, Jacka FN, et al. So depression is an inflammatory disease, but where does the inflammation come from? BMC Med 2013;11:200.

34. Juanola-Falgarona M, Salas-Salvadó J, Estruch R, et al. Association between dietary phylloquinone intake and peripheral metabolic risk markers related to insulin resistance and diabetes in elderly subjects at high cardiovascular risk. Cardiovasc Diabetol 2013;12:7.

35. Yates KF, Sweat V, Yau PL, et al. Impact of metabolic syndrome on cognition and brain: a selected review of the literature. Arterioscler Thromb Vasc Biol. 2012;32(9):2060-7.

36. Freeman LR, Haley-Zitlin V, Rosenberger DS, et al. Damaging effects of a high-fat diet to the brain and cognition: A review of proposed mechanisms. Nutr Neurosci 2014;17(6):241-51.

37. Kosari S, Badoer E, Nguyen JCD, et al. Effect of western and high fat diets on memory and cholinergic measures in the rat. Behav Brain Res 2012;235:98-103.

38. Kanoski SE, Davidson TL. Different patterns of memory impairments accompany short- and longerterm maintenance on a high-energy diet. J Exp Psychol Anim Behav Process 2010;36(2):313-9.

39. Jurdak N, Kanarek RB. Sucrose-induced obesity impairs novel object recognition learning in young rats. Physiol Behav 2009;96:1-5.

40. Ramos JMJ. Long-term spatial memory in rats with hippocampal lesions. Eur J Neurosci 2000;12(9):3375-84.

41. Antunes M, Biala G. The novel object recognition memory: neurobiology, test procedure, and its modifications. Cogn Process 2012;13(2):93-110.

42. Chouet J, Ferland G, Féart C, et al. Dietary vitamin $\mathrm{K}$ intake is associated with cognition and behavior among geriatric patients: The CLIP ctudy. Nutrients 2015;7:6739-50.

43. Broadbent NJ, Squire LR, Clark RE. Spatial memory, recognition memory, and the hippocampus. Proc Natl Acad Sci USA. 2004;101(40):14515-20.

\title{
Витамин К2 оказывает положительное влияние при состояниях беспокойства и депрессии, не влияя на когнитивные способности крыс с метаболитным синдромом: роль сахара в крови?
}

\author{
Сильвия М. Ганчева, Мария Д. Желязкова-Савова \\ Кафедра доклинической и клинической фармакологии, Медицинский университет, Варна, Болгария
}

Адрес для корреспонденции: Сильвия М. Ганчева, Кафедра доклинической и клинической фармакологии, Медицинский университет - Варна - ул.

Марина Дринова № 55, г. Варна, 9002, Болгария

E-mail: silvi_gancheva@abv.bg Тел.: +359887497689

Дата получения: 11 ноября 2015 г.

Дата приемки: 05 июля 2016 г. Дата онлайн публикации: 05 октября 2016 г.

Дата публикации: 23 декабря 2016 г.

Ключевые слова: витамин K2, метаболитный синдром, беспокойство, депрессия, связь с уровнем сахара в крови

Образец цитирования: Gancheva SM, ZhelyazkovaSavova MD. Vitamin K2 improves
Контекст: Метаболический синдром является социально значимым расстройством утилизации и хранения энергии в организме и признается в качестве фактора, предрасполагающего к развитию депрессии, тревожности и когнитивных нарушений у людей.

Цель: В рамках данного исследования нами был проведен анализ воздействия витамина К2 на поведение крыс с метаболитным синдромом и исследована связь с воздействием на уровень сахара в крови.

Материалы и методы: Мужские особи крыс линии Вистар были разделены на четыре группы: контрольная группа с нормальным питанием для крыс, группа с метаболитным синдромом (MC), которой подавался корм с богатым содержанием жиров на основе высокофруктозной диеты, контрольная группа, которая получала витамин K2, и МС група, которая получала витамин К2. Витамин К2 подается через зонд. В конце исследования (спустя 10 недель) были проведены поведенческие тесты и определен уровень сахара в крови на голодный желудок. Уровень беспокойства определяется с помощью теста на социальное взаимодействие, а уровень депрессии оценивается с помощью теста Порсолта. Воздействие на память оценивается с помощью теста на идентификацию объектов. Проведен анализ связи между уровнем сахара в крови, установленным на голодный желудок, и результатами поведенческих тестов.

Результаты: У крыс в составе МС группы установлен повышенный уровень сахара в крови. У них наблюдалось состояние беспокойства, депрессии и по- 
anxiety and depression but not cognition in rats with metabolic syndrome: a role of blood glucose?

Folia Medica 2016;58(4): 264-272 doi: 10.1515/folmed-2016-0032 тери памяти. За счет витамина К2 был нормализован уровень сахара в крови, понизился уровень беспокойства и депрессии, но память не улучшилась. Время социального взаимодействия (обратный индекс беспокойства) и идентифицирующая функция памяти находятся в обратной зависимости от уровня сахара в крови у крыс, не подверженных воздействию, а время неподвижности (мера измерения депрессии) - нет. Когда были добавлены крысы, которым подавался витамин К2, связь уровня сахара в крови со временем социального взаимодействия поддерживалась, однако связь с идентифицирующей функцией памяти была утрачена.

Заключение: Настоящее исследование установило, что витамин К2 предотвращает развитие тревоги и депрессии, но не улучшает дефицит памяти, вызванный диетическими манипуляциями в экспериментальной модели метаболического синдрома. В связи с этим можно предполагать, что анксиолитический эффект от применения витамина К2 проявляется частично из-за его воздействия на содержание глюкозы в крови, в то время как антидепрессивный эффект является глюкозонезависимым. 